\title{
Why Do We Teach? Adult Learning Theory in Professional Standards as a Basis for Curriculum Development
}

\section{Donald L. Gilstrap}

This article provides an overview of adult learning theory in relation to teaching philosophies among librarians belonging to ACRL, using Hadley's Educational Orientation Questionnaire. Although not significant as a predictor, there was a nonlinear and negative correlation between librarians' familiarity with the ACRL Standards and their adult learning orientation scores $(p=.047, t<.05)$. Additional variables are included to investigate other influences on adult learning orientation scores. Results of the study showed high significance for gender $(B=0.213, p=0.008)$, current library instruction ( $\beta=0.199, p=0.025)$, and the number of library instruction classes taught during the current year $(B=0.199, p=0.041)$. Additional descriptive statistical analysis and qualitative responses are included, and propositions for professional development are then introduced for future discussions among the ACRL community about the importance of adult learning as well as the evolution of our teaching philosophies.

\begin{abstract}
"When did you decide to stop being a teacher?" The question came to me during a job interview; it struck me as strange. At the time it was asked, I had just completed a one-hour presentation... When did I decide to stop being a teacher? Hadn't I just been teaching a few minutes ago?'
\end{abstract}

When I first read Scott Walter's quote in his College $\mathcal{E}$ Research Libraries article, it refreshed many wonderful memories of my work in Library Instruction over the years. When the Association of College \& Research Libraries (ACRL) released the Information Literacy Competency Standards for Higher Education: Standards, Outcomes, and Performance Indicators in $2000,{ }^{2}$ it was an exciting time for me. Prior to this, I had led a heavily used library instruction program at an urban university and, with the help of colleagues, had performed a universitywide pre- and post-testing assessment of freshman student performance in library instruction. However I realized that, at the time, the absence of professional standards and library science theory on this subject made it difficult to develop theoretical propositions to assess accurately student learning with any depth. In 2000, I was integrating a new library instruction program in a different academic library, and the emergence of the ACRL Standards was used as a basis for our thinking about cur-

Donald L. Gilstrap is Dean and Professor of University Libraries and Professor of Educational Leadership at Wichita State University; e-mail: Donald.Gilstrap@wichita.edu. (C) 2013 Donald L. Gilstrap, AttributionNonCommercial (http://creativecommons.org/licenses/by-nc/3.0/) CC BY-NC 
riculum development. At my next institution, we completely redesigned our library instruction curriculum, using the ACRL Standards as foundations for each aspect of our tiered approach to instruction. We subsequently performed assessment on both student learning and the curriculum, and the incorporation of these standards was critical to that program's success. ${ }^{3}$ So it is without hesitation that I have been a vocal advocate for the creation and application of the ACRL Standards to help move our library instruction programs progressively forward. And the concept of "What does it mean to teach?" has been at the forefront of my thinking for many years.

We have also seen a great deal of change within our libraries during the past few years as a result of economic crises, the emergence of high-impact technologies, and expanded professional thinking about the future of librarians. Many have advocated for librarians as educators in the library of the twenty-first century, and several studies have proven this important role, too numerous to cite just within the pages of $C \mathcal{E} R L$ alone. However I also find myself realizing that we need to ask ourselves, "How well do we really understand and use these standards, and how should we proceed in the future of library instruction development as a professional organization?"

In the ACRL Standards, we see direct and specific evidence of the need to focus on recursive student-centered curricula, including lifelong learning, self-directed learning, and critical thinking.

\section{Developing lifelong learners is central to the mission of higher education institutions. By ensuring that indi- viduals have the intellectual abilities of reasoning and critical thinking, and by helping them construct a framework for learning how to learn, colleges and universities provide the founda- tion for continued growth throughout their careers, as well as in their roles as informed citizens and members of communities. Information literacy is a}

key component of, and contributor to, lifelong learning.

Gaining skills in information literacy multiplies the opportunities for students' self-directed learning, as they become engaged in using a wide variety of information sources to expand their knowledge, ask informed questions, and sharpen their critical thinking for still further self-directed learning. ${ }^{4}$

At the same time, the ACRL Instruction Section recently promoted an update on the Research Agenda for Library Instruction and Information Literacy, including (among other things) a section on Teaching that addresses questions such as the theoretical bases, methodologies, and design of library instruction curricula. ${ }^{5}$ Their most recent survey of the ACRL membership on this subject highlights the need to reevaluate these questions ten years later, assessing membership interests in much deeper theoretical investigations of teaching and learning processes in library instruction. ${ }^{6}$

While following the progress that has been made by ACRL on library instruction initiatives, my own research has investigated the theoretical constructs of teaching and learning and how we choose to integrate theory into our research. While we have made great strides in advancing the library instruction agenda, we are still relatively nascent in creating theoretical bases for the application and subsequent assessment of teaching and learning. However, there are a great number of strong theories that have been developed and tested in education and social sciences disciplines. One aspect of this pertains to adult learning theory, although it has not been addressed with much depth in the library science research. Integrating an interdisciplinary framework for understanding, it is the purpose of this research to investigate professional perceptions of adult learning theory in relation to professional standards as a means to develop library instruction curriculum theory in the future. 


\section{Literature Review}

The concept of adult learning in higher education emerged primarily during the twentieth century through the early works of Dewey, Lindeman, and Ortega y Gasset and evolved from the psychological development theory of Rogers, Kegan, and Belenky et al. to the later works on the andragogical theory of Knowles. ${ }^{7}$ When placed in their respective contexts, the differences between the theoretical constructs of andragogy and pedagogy are significant. Pedagogy derives from the Greek $\pi \alpha$ เoós, or paidos: children; in other words, the study of teaching and learning among children. Andragogy was first introduced to Malcolm Knowles from the European community, and he started integrating the term into U.S. educational circles in the late 1960s to differentiate adult learning from the study of childhood learning. Knowles argued that pedagogically oriented curriculum plans focus primarily on content only, whereas adult learning plans incorporate a "process design" where the student gains skills and experiences that help her/him to apply this design repeatedly as new knowledge is sought out, relating directly to the lifelong and self-directed learning addressed in our own ACRL Standards. Learning is not a linear event; rather it is a systemic process, and Knowles did not intend for these constructs to be in direct opposition to one another. Consequently, Knowles viewed the terms on a continuum where pedagogy moved toward andragogy as children developed into adulthood. ${ }^{8}$ Moreover, Knowles' unique focus on issues such as experience and maturity among adult learners help guide instructors on how much self-directed learning they encourage within their classes.

As an operational definition, andragogy is "a learner-centric approach to learning," whereas pedagogy is "dominated by the instructor-centric theories." Andragogy focuses on the following assumptions:

Adults require that the instructor provide a rationale for why they need to learn the new information prior to learning it [need to know]... adults have a defined identity... they dislike being told what to do, as is often the case in a pedagogic learning environment [self-concept]... they become fearful when placed in a pedagogic learning environment where the teacher seeks to be an authority figure, rather than a facilitator of knowledge [motivation to learn]... adults are ready to learn when they make a decision that the content to be provided in the learning experience will be helpful for their real-life activities [readiness to learn]. ${ }^{9}$

In a real-world setting for library instruction, this implies that we explain why the concepts we are teaching are important, that we help guide our students in a self-directed manner, and that the purposes of library instruction should match existing or evolving research requirements in university courses. Additionally, for the purposes of this article, I will primarily use the more contemporary term adult learning theory when discussing andragogical concepts.

Some of the most significant and practical aspects of the differences between pedagogy and adult learning theory arise from epistemological views of learning. Pedagogical theory tends to focus on rote memorization, operating under the assumption that children's brains are empty vessels in which we need to deposit knowledge. Granted, this does serve a purpose, such as when learning multiplication tables or verb conjugations for foreign languages. Adult learning theory makes the assumption that the learner has developed toward higher levels of learning and is at a stage where $\mathrm{s} /$ he can focus on learning how to learn. At this stage, pedagogical learning serves more as a kit of tools already acquired that help further the adult learning process. From the perspective of library instruction, one example might highlight pedagogical techniques as "Here is where you click to 
retrieve peer-reviewed articles for your assignment" where the adult learning approach might highlight, "How can you tell if a journal is peer reviewed and what is the importance of peer review in scholarly communication?" Both serve a purpose in the library instruction classroom, but the adult learning approach places emphasis on critical thinking when performing research and certainly adds much more value to the learning environment.

In a similar vein, there is another model that synthesizes the seemingly dichotomous nature of pedagogy versus adult learning theory. Researchers such as Grow and Delahaye or Limerick and Hearn present theories of adult learning based on Hersey and Blanchard's Situational Leadership Model that posit the learner in a quadrant continuum between pedagogy and adult learning based on her/his maturity level. ${ }^{10}$ However, in his well-known critique of these works, Tennant challenged this approach through the epistemological paradox of who is best suited to specify which stage a student falls into, the teacher or the learner, and who determines when a learner moves to a different stage $?^{11}$ Grow subsequently addressed each of these issues in his later work, noting that there is no single model for adult learning, and instruction modes are often dependent on the situation of the learner. ${ }^{12}$

During the 1970s, Herschel Hadley's research on Knowles' adult learning theory led to his development of the Educational Orientation Questionnaire. This instrument was designed to assess adult educators' proclivities toward pedagogical or adult learning teaching methods based on attitudinal dimensions of teaching and learning processes. For Hadley's sample population $(n=409)$, he chose adult educators from several different disciplines from both higher education and the private sector. Reliability and validity of the instrument was tested through numerous means, including intraclass correlation, test/retest reliability, and multiple regression coefficients analysis. Factor analysis highlighted adult educators' pedagogical and adult learning orientations, while creating generalizable standardized scores that could be applied to the adult education community at large. Since the time of Hadley's original research, the Educational Orientation Questionnaire has been used numerous times in different disciplines while further validating the instrument as a strong measure of adult learning theory. ${ }^{13}$

In library science scholarship in the early 1990s, Naito used Hadley's Educational Orientation Questionnaire in an investigation of bibliographic instruction librarians for her dissertation research. This study included those librarians who were members of the ACRL Bibliographic Instruction Section $(n=379)$. Her findings showed that: librarians typically exhibited both pedagogical and adult learning traits; that librarians were generally more adult learning oriented; that females' rates of adult learning orientation were significant; that the number of years of experience teaching led to higher adult learning scores; that librarians teaching instruction sessions in short formats tended to be oriented more toward adult learning; that librarians who had coursework in education showed higher adult learning scores; and that higher class size and lower student enrollment at an institution influenced librarians' adult learning scores significantly. ${ }^{14}$

Additionally, the roles of library science programs have some bearing on influencing librarians' orientations toward adult learning. Westbrock and Fabian draw attention to the dichotomy between what is taught in library science programs and what is needed in library instruction classrooms. Reconducting Shonrock and Mulder's 1986 study of library instruction proficiencies, and drawing on several research studies that have taken place since that time, Westbrock and Fabian found that the newer 2007 ACRL Proficiencies for Instruction Librarians were more closely aligned with the real-world teaching experiences of librarians. However, 
most notably, these authors, as well as many others, also found that the vast majority of librarians teaching informationliteracy courses gained their skills on the job and not during their graduate studies in library science programs, which has been shown at other institutions. ${ }^{15}$

\section{Research Design}

As stated previously, the purpose of this research is to investigate professional perceptions of adult learning theory in relation to professional standards as a means to develop library instruction curriculum theory in the future. Several adult learning inventories are available to help guide tests of the strength of adult learning orientation among librarians in relation to variables that might determine the emergence of this phenomenon. Equally, previous studies have shown that mainstream instruments yield similar results. Hadley's Educational Orientation Questionnaire was chosen for this research for a number of reasons. As stated previously, the questionnaire has been in use for over 30 years and has been field tested in a variety of different disciplines. Research studies have consistently upheld reliability and validity analyses, adding strength to its generalizability in a number of different disciplines. It should also be noted that much has changed in academic libraries since Naito's study: foremost, the creation of the ACRL Information Literacy Competency Standards. This study is designed to reinvestigate and confirm variables used in Naito's original study. Moreover, Naito posited the Educational Orientation Questionnaire in relation to a particular ACRL section, while this study randomly samples the entire population of ACRL as an attempt to focus greater generalizability on the membership of this professional organization. Due to issues of copyright and the length of the Educational Orientation Questionnaire, readers are encouraged to explore the original instrument. ${ }^{16}$

The total membership of the Association of College \& Research Libraries $(N \approx 12,000)$ was used as the population for this study, and random sampling of this population was used for the purposes of variable testing. The main hypothesis test was to determine the prediction strength between the two continuous variables: 1) familiarity with the ACRL Information Literacy Competency Standards on the variable; and 2) the adult learning orientation scale. Additional variables were also investigated; therefore, sample size was calculated conservatively for continuous variables ( $n=119, \alpha=0.05, \underline{t}=1.96)$ with a strong margin of error of \pm 0.03 . However, additional categorical and ordinal variables were also included in this research, so conservative sample size calculations were increased $(n=264, p=0.5, \underline{t}=1.65)$ with a normal margin of error of $\pm 0.05 .{ }^{17}$ Based on previous studies of this type, it was estimated that this study would elicit roughly a 30 percent response rate, so random sampling of the ACRL membership led to a total sample population of 650 individuals.

After random sampling had been performed, a demographics questionnaire [Appendix A] and the Educational Orientation Questionnaire were e-mailed to 650 potential participants. The demographics questionnaire was useful in gathering information about study participants in relation to their self-assessment of adult learning orientation, such as whether they teach library instruction and how much, their gender, age, whether they held additional advanced degrees, the size and geographic location of the institution where they received their MLS, how many years they have worked as a librarian, whether they currently teach library instruction, and how many instructional sessions they teach during the year. Of the original 650 possible participants, 233 participants completed the demographics questionnaire and $E O Q$, roughly the original sample size estimate for both continuous and categorical variables. Data were further reduced to those participants who had completed every question on the demographics questionnaire and EOQ. Therefore, the sample used for this study is $n=162$. 


\section{Limitations}

Due to the large number of questions the Educational Orientation Questionnaire entails, this study was susceptible to maturation effects. Given considerable time constraints of contemporary academic librarians, it was difficult for several participants to complete all sixty questions on the instrument in addition to the demographics questions in their entirety. Although response rates were much higher for participants who did not complete every question, this researcher only included data where all responses were recorded and none left blank to add to the robustness of the data and strength of the regression model. Conversely, this strategy reduced the sample size to $n=162$ from the original $n=264$ for categorical variables, therefore changing the general confidence level to 90 percent to maintain a margin of error of \pm .05 while the margin of error for continuous variables remained very strong at \pm .03 with a 95 percent confidence level for the original population of ACRL members $(N \approx 12,000)$. This sample size is very strong for continuous variables, and the strength of the regression model adds to the power of data analysis for categorical variables. However, it must be pointed out that the sample size is smaller than originally estimated, which can influence different interpretations of this study's results on categorical variables. Therefore, additional specificity used with descriptive statistics helps to reduce this influence and adds to the interpretation strength of the study's findings.

\section{Findings}

The main hypothesis test was to determine the strength of prediction of the variable How familiar are you with the Association of College $\mathcal{E}$ Research Libraries Information Literacy Competency Standards on the variable Adult Learning Orientation Scores. An initial 2-tailed Pearson's R correlation test was performed but was not found to be significant. An additional nonparametric test, Spearman's rho, was also performed, and the two variables did show the existence of a significant nonlinear correlation $(p=.047$, $t<.05)$. In other words, since the Pearson's R coefficient $(r=-.097)$ is different from the Spearman's rho $\left(r_{s}=-.156\right)$, we can conclude that a correlation exists but in a nonlinear fashion. These two variables, taken only by themselves, do not present a plausible case for correlation, but it is inferred that additional variables add to the significance of this correlation in nonlinear ways.

Multiple regression analysis, therefore, was performed on the independent and dependent variables within the study. As was noted earlier, nonlinear relationship for librarians' familiarity with the ACRL Information Literacy Competency Standards in relation to their Educational Orientation Questionnaire scores appeared, and multiple regression takes into account interaction effects at various dimensions of the regression model. Based on theoretical assumptions from the literature review, the following independent variables were included in the regression analysis to help explain the phenomenon of adult learning orientation among different librarians: 1) familiarity with ACRL Standards; 2) gender; 3) age; 4) geographical location of the institution where the librarian received his/her MLS; 5) the size/scope of the MLSgranting institution; 6) additional graduate degrees held by the librarian; 7 ) how many years the person served as a professional librarian; 8) whether the librarian currently teaches library instruction; and 9) how many instructional sessions the librarian teaches per year.

An ANOVA test of the strength of the regression model was significant $[\mathrm{F}=5.196$, $d f(10), \beta=.193, p=.016]$, greatly reducing the number of Type I errors. An effect size above the $50 \%$ percentile standing $\left(R^{2}=\right.$ .037) was found taken in comparison with the expected effect size $[k(6-1) / n(162-1)=$ $0.031]$ for a .90 probability of rejecting the null with $\alpha=.10 .^{18}$ Histogram and Normal P-P scatter plots of standardized residuals showed that the assumptions of homoscedasticity and linearity were met, and the data is normally and randomly distributed. Results of the multiple regression analysis 
showed high significance for the following variables: 1$)$ gender $(\beta=.213, p=.008)$, 2) currently teach library instruction $(\beta=$ $.199, p=.025)$, and 3) the number of library instruction classes taught during the current year $(\beta=.199, p=.041)$. The remaining independent variables were not found to be significant confirmatory variables for this study. Zero-order and part correlations show that gender accounts for 4 percent of the variance in overall adult learning scores, and, as a predictor, it accounts for 4 percent of the variance in adult learning scores above the variance accounted for by the other predictor variables. Currently, teaching library instruction accounts for 3 percent of the variance in overall adult learning scores, and, as a predictor, it accounts for 3 percent of the variance in adult learning scores above the variance accounted for by the other predictor variables. The number of library instruction classes taught accounts only for less than 1 percent of the variance in overall adult learning scores, but, as a predictor, it accounts for 3 percent of the variance in adult learning scores above the variance accounted for by the other predictor variables.

\section{Analysis}

An analysis of this research study's findings reveals several issues and possible trends in academic library instruction at the current time. As one participant pointed out:

\section{I think every teacher has different methods of teaching based on their strengths-some may be engaging lec- turers, while others can manage group projects well. I thought this survey was an interesting exploration of different teaching philosophies.}

Equally, since a nonlinear correlation emerged between adult learning scores and familiarity with the ACRL Standards scores, further analysis of descriptive statistics helps reveal the complex interdependence of variables and how they influence the dependent variable.
It can be argued that different age and degree matriculation demographics might influence the evolution of curriculum development in library instruction with younger librarians seeking a more adult learning-oriented framework for teaching, while older librarians tend to be focused more pedagogically. Although age has been used as a variable of influence for many research studies in $C \mathcal{E} R L$, age was not shown to be a significant predictor for this study. Whereas Naito's original study found no significance for the number of years of library instruction experience, ${ }^{19}$ descriptive statistics for this study reveal that librarians with both 11 or more years of experience and those who received their MLS prior to 2001 tended to have higher adult learning scores than those librarians with both 10 or fewer years of experience and those who received their MLS since 2001. This is manifested in the experiential insights by participants in the former category. As one example, a participant in this category stated:

\section{I believe problem-based learning, proj- ect-based learning and other collab- orative approaches are useful to help motivate and engage students.}

Statements such as these are contrasted by those of recent MLS graduates who have few years of experience. When looking at library instruction, many did not fully identify with teaching and learning experiences as exemplified by this statement:

\section{What is this "teacher/student" thing? I'm a librarian and not the professor of a class.}

Further research is needed to explore why librarians matriculating from library and information science programs within the past 10 years tend to have a teaching philosophy that appears to be in conflict with the results of Naito's study in the 1980s and that is in opposition to the evolution of both the ACRLStandards and main- 
stream curriculum theories. Viewing the ACRL Standards specifically, this shows that, while we should be teaching students critical thinking and lifelong learning, we are struggling as a profession to embrace those same concepts in our own learning.

Conversely, those librarians who currently teach library instruction $(\beta=0.199$, $p=0.025)$ and the number of instructional sessions they teach $(\beta=0.199, p=0.041)$ were found to be significant predictors of increased adult learning orientation scores. Moreover, differences in mean scores on whether library instruction was a main job function of an individual were negligible. Therefore, outside of gender, the most accurate predictors of adult learning orientation related to librarians' experience in the classroom. Those people who teach more library instruction sections regardless of job classification or primary job responsibility have a greater tendency to seek out curriculum methods that foster adult learning. This was evident among study participants who currently teach more than 40 library instruction sessions a year, exemplified in the statement by one such librarian:

To me, significant learning experiences are collaborative, interactive, engaging, and involve student input as well as a feedback loop.

Equally, as has been shown in previous studies of curriculum assessment, ${ }^{20}$ this research confirms that experience among librarians is a more accurate predictive variable on library instruction than the age of the instructor.

Extending this concept, the original Pearson's R test showed a significant correlation between the number of years as a librarian and whether library instruction is a main job function $(p=.01)$. Analyzing descriptive statistics, we find that the current trend for this study reveals that the longer one has been a librarian, the less likely it is that library instruction is a main job function. Furthermore, the longer one has been a librarian, the fewer library instruction sessions that person teaches (see figure 1). This analysis is revealing, since experience has been shown to be a significant predictor as well as producer of higher mean scores on adult learning orientation in relation to the ACRL Standards.

Gender was found to be a significant predictor of adult learning orientation in this study $(p=.008)$, which confirms this variable as a predictor in other studies of library instruction programs performed using the Educational Orientation Questionnaire. ${ }^{21}$ However, for this study in particular, male librarians tended to have mean adult learning scores $\left(\bar{x}_{m}=88.15\right)$ that were significantly higher than their female colleagues $\left(\bar{x}_{f}=83.31\right)$. In a general research framework, this finding diverges from scholarship on adult educators in different fields and adult learners outside library science where women have tended to integrate adult learning concepts into

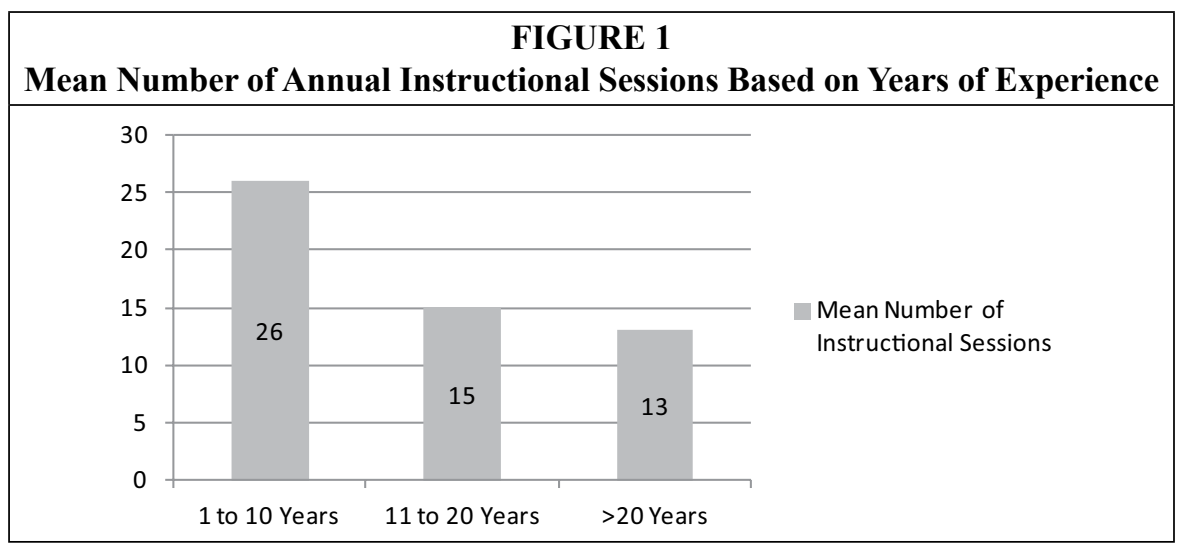


the classroom. ${ }^{22}$ However, analysis of mean scores upholds the proposition that years of experience as a librarian has a great influence on adult learning score outcomes, including when clustering for gender: those females with 11-20 years of experience had the highest mean scores $(\bar{x}=85.05)$, whereas those females with 10 or fewer years of experience had the lowest mean scores $(\bar{x}=80.52)$. These same phenomena were consistent for male adult learning scores: those males who had 10 or fewer years of experience had the lowest mean scores $(\bar{x}=84.90)$, whereas those males who had 21 years of experience or more had the highest mean scores $(\bar{x}=90.81)$.

As the importance of library instruction has grown significantly during the past 10 years, many libraries have implemented strategies that seek out recent graduates to fill positions where high numbers of instructional sessions are taught. On a practical level, these new professionals bring a great deal of technological skills, information theory, and contemporary experiences to the classroom to which university students easily identify and respond. Regarding curriculum development, however, this study has shown that newer librarians in recent years tend to identify more with pedagogical learning orientations where their colleagues with more years of experience hold more adult learning orientations. Reinforcing that age is not a significant predictor, but rather experience is on adult learning orientation: in the apparent absence of educational learning theories in library science programs, it might be inferred that librarians are learning on the job many of the educational and curriculum theories and practices that lead to more effective teaching and learning environments in higher education. Naito's original study also found that those librarians holding PhDs in library science tended to be more pedagogically oriented overall, whereas those librarians who held PhDs in other fields tended to be more adult learning oriented. Furthermore, in 2002, Albrecht and Baron found that "SLIS programs are reluctant to embrace [library instruction] as a core requirement of librarians... While we hoped new literacy standards would elicit a response from SLIS programs in the form of required-or even regularly scheduled-courses, we were not able to determine this." ${ }^{23}$ Almost ten years later, research from this study tends to support this and challenges us as a profession to address this phenomenon in more detail and with criticality. It very well may be the distinguishing factor in developing the next stages of ACRL library instruction initiatives in the future.

This study also looked at the geography and scope of the institution where a participant received her/his MLS. However, these independent variables did not prove to be significant, showing that geographical location or institutional comprehensiveness were not influential. Mean scores $(\bar{x}=84.50)$ for those librarians who received their degrees from universities with the Carnegie Classification of Very High and High Research Activity (RU/VH and RU/H) were almost identical to mean scores $(\bar{x}=84.61)$ of those who received their degrees from smaller institutions (such as DRU and Master's L). Geographical location of the degree-granting institution was also not a significant predictor of adult learning orientation. However, mean scores were highest among MLS-granting institutions in Canada $(\bar{x}=89.50)$ and the West Coast ( $\bar{x}=86.03)$, followed closely by institutions on the East Coast $(\bar{x}=85.42)$ and Southern $(\bar{x}=85.28)$ regions with the Midwest coming in with the lowest mean scores $(\bar{x}=$ 81.49). Along those same lines, however, librarians working at medium $(\bar{x}=85.58)$ and small libraries $(\bar{x}=84.41)$ had higher adult learning mean scores than those librarians working at research universities $(\bar{x}=83.48)$. This finding confirms Naito's original finding, that "the largest number of andragogical responses came from those teaching at institutions of 1,000 or fewer students," whereas those at larger institutions "were significantly more in 
disagreement than expected." 24 More research is needed to explore these phenomena in detail, but, again, library science programs and subsequent institutional affiliation seem to have some impact on influencing an individual's teaching and learning orientation.

Although not significant as a predictor when taken in relation to the other independent variables, descriptive statistics reveal that the management of people has some influence on adult learning orientation. Those librarians who both managed people and who managed more than 10 people tended to have higher mean adult learning scores $(\bar{x}=85.00)$ than their counterparts $(\bar{x}=83.47)$. Consequently, management and organizational development theories take into account learning development, and supervisors might thereby be influenced by these schools of thought. Equally, the real-world experiences of managing people tend to teach supervisors a great deal about learning development among individuals, which suggests subsequent influences on adult learning orientation in library instruction. As one participant in this category pointed out in response to this research:

\section{It's obvious that the more involved students become in their own learning, the more successful they will be. It's im- portant for both teachers and students to be aware of learning styles and to address a variety of them in a classroom.}

Further research is needed to explore this phenomenon in more detail, but this study suggests there is a great deal of potential research to explore the connections and influences between management theory and adult learning theory in library instruction.

Perhaps most important for this research is the relationship between the independent variable familiarity with the ACRL Standards and the dependent variable adult learning scores. Although the variable was not found to be a significant predictor in the multiple regression analy- sis, Spearman's rho showed a negative correlation between this independent variable and the dependent variable $(r=-0.156$, $p=.047, t<.05)$. Further analysis of descriptive statistics showed that mean scores for pedagogical orientation among librarians were slightly higher than mean scores for adult learning orientation $\left(\left(\bar{x}_{p}=85.16\right)>(\right.$ $\left.\left.\bar{x}_{a}=84.53\right)\right)$. When analyzed more specifically, adult learning scores were highest when compared to familiarity with the ACRL Standards at the percentiles of somewhat familiar $(\bar{x}=87.72)$ and very familiar $(\bar{x}=84.89)$. Conversely, mean scores for adult learning orientation were lowest at the extreme percentiles of not familiar $(\bar{x}=$ $82.86)$ and extremely familiar $(\bar{x}=82.00)$. It must be stressed that in this study, those librarians who identified as having more experience with the ACRL Standards actually had the lowest mean adult learning scores. The scope of this research does not allow for why this phenomenon has taken place, and, for this reason, additional research within the profession is highly suggested.

\section{Conclusion}

So, when I think about information literacy now, I am able to see it as a learning initiative, rather than simply a library initiative. ${ }^{25}$

As has been stated previously, the very creation of these standards by the ACRL community contained language that highlights curriculum designs oriented toward adult learning. When taken in comparison to Naito's study, which preceded the creation of the ACRL standards, this current research finds an opposite trend moving in a direction that is more pedagogical, or child-centered, in nature. Although many years have passed, when the results of this study are compared to the more general adult educator community in higher education, mean standardized scores for librarians in this study $(\bar{x}$ $=-1.586$ ) were in the bottom 10 percent, where only 6 percent of adult educators in all fields had lower standardized 


\begin{tabular}{|c|c|c|c|c|c|}
\hline \multicolumn{6}{|c|}{$\begin{array}{c}\text { TABLE } 1 \\
\text { Mean Adult Learning Scores Stratified by Variable }\end{array}$} \\
\hline & Value & $\mathbf{n}=$ & $\begin{array}{c}\text { Adult } \\
\text { Learning } \\
\text { Mean }\end{array}$ & $\begin{array}{c}\text { Std. } \\
\text { Deviation }\end{array}$ & $\begin{array}{c}\text { Std. } \\
\text { Error } \\
\text { of } \\
\text { Mean }\end{array}$ \\
\hline \multicolumn{6}{|l|}{ Independent Variable } \\
\hline \multirow{2}{*}{$\begin{array}{l}\text { Provide Reference } \\
\text { Service }\end{array}$} & Yes & 148 & 84.61 & 11.14 & 0.93 \\
\hline & No & 14 & 83.71 & 12.97 & 3.02 \\
\hline \multirow[t]{2}{*}{ Gender } & Female & 121 & 83.31 & 11.39 & 1.01 \\
\hline & Male & 41 & 88.15 & 10.21 & 1.73 \\
\hline \multirow[t]{3}{*}{ Age } & $20-35$ & 41 & 81.59 & 9.14 & 1.75 \\
\hline & $36-50$ & 55 & 85.71 & 12.00 & 1.52 \\
\hline & $>50$ & 66 & 85.38 & 11.67 & 1.39 \\
\hline \multirow{2}{*}{$\begin{array}{l}\text { Additional } \\
\text { Graduate Degrees }\end{array}$} & Yes & 68 & 84.68 & 12.24 & 1.16 \\
\hline & No & 94 & 84.43 & 10.52 & 1.37 \\
\hline \multirow[t]{3}{*}{ Year Received MLS } & $1960-1985$ & 32 & 86.09 & 12.55 & 1.99 \\
\hline & $1986-2000$ & 58 & 85.21 & 11.12 & 1.48 \\
\hline & 2001-Present & 72 & 83.29 & 10.81 & 1.33 \\
\hline \multirow[t]{2}{*}{$\begin{array}{l}\text { MLS by University } \\
\text { Type }\end{array}$} & $\begin{array}{c}\text { Comprehensive } \\
\text { Research University }\end{array}$ & 113 & 84.50 & 10.34 & 1.06 \\
\hline & $\begin{array}{l}\text { Medium-sized } \\
\text { University }\end{array}$ & 49 & 84.61 & 13.29 & 1.62 \\
\hline \multirow{5}{*}{$\begin{array}{l}\text { MLS by University } \\
\text { Geography }\end{array}$} & East & 33 & 85.42 & 12.99 & 1.96 \\
\hline & South & 46 & 85.28 & 8.59 & 1.66 \\
\hline & Midwest & 43 & 81.49 & 11.96 & 1.72 \\
\hline & West & 38 & 86.03 & 10.74 & 1.82 \\
\hline & International & 2 & 89.50 & 6.36 & 7.85 \\
\hline \multirow[t]{3}{*}{ Years as a Librarian } & 1 to 10 & 77 & 83.10 & 10.66 & 1.29 \\
\hline & 11 to 20 & 46 & 85.98 & 11.23 & 1.68 \\
\hline & $>20$ & 39 & 85.74 & 12.51 & 1.81 \\
\hline \multirow[t]{2}{*}{ Job Type } & Public Services & 122 & 84.88 & 11.73 & 1.03 \\
\hline & $\begin{array}{c}\text { Technical Services/ } \\
\text { Systems }\end{array}$ & 40 & 83.48 & 9.79 & 1.87 \\
\hline
\end{tabular}


TABLE 1

Mean Adult Learning Scores Stratified by Variable

\begin{tabular}{|c|c|c|c|c|c|}
\hline & Value & $\mathbf{n}=$ & $\begin{array}{c}\text { Adult } \\
\text { Learning } \\
\text { Mean }\end{array}$ & $\begin{array}{c}\text { Std. } \\
\text { Deviation }\end{array}$ & $\begin{array}{l}\text { Std. } \\
\text { Error } \\
\text { of } \\
\text { Mean }\end{array}$ \\
\hline \multirow[t]{2}{*}{ Manage People } & Yes & 76 & 85.74 & 11.62 & 1.29 \\
\hline & No & 86 & 83.47 & 10.91 & 1.21 \\
\hline \multirow{3}{*}{$\begin{array}{l}\text { How Many People } \\
\text { Do You Supervise }\end{array}$} & 0 & 75 & 83.49 & 11.10 & 1.30 \\
\hline & 1 to 10 & 77 & 85.48 & 10.94 & 1.29 \\
\hline & $>10$ & 10 & 85.00 & 15.20 & 3.59 \\
\hline \multirow{3}{*}{$\begin{array}{l}\text { Size of Academic } \\
\text { Library in Which } \\
\text { You Work }\end{array}$} & Small & 66 & 84.41 & 12.75 & 1.39 \\
\hline & Medium & 52 & 85.58 & 11.01 & 1.57 \\
\hline & Large/Research & 44 & 83.48 & 9.14 & 1.71 \\
\hline \multirow{2}{*}{$\begin{array}{l}\text { Currently Teach } \\
\text { Library Instruction }\end{array}$} & Yes & 126 & 83.63 & 10.26 & 1.00 \\
\hline & No & 36 & 87.69 & 13.97 & 1.86 \\
\hline \multirow{2}{*}{$\begin{array}{l}\text { Is LI One of Your } \\
\text { Main Job Functions }\end{array}$} & Yes & 103 & 84.61 & 11.29 & 1.11 \\
\hline & No & 59 & 84.39 & 11.32 & 1.47 \\
\hline
\end{tabular}

\begin{tabular}{|l|c|c|c|c|c|}
\hline $\begin{array}{l}\text { Approximately How } \\
\text { Many LI Sessions }\end{array}$ & 0 & 56 & 83.38 & 10.39 & 1.51 \\
\cline { 2 - 6 } $\begin{array}{l}\text { Did You Teach This } \\
\text { Year }\end{array}$ & 1 to 10 & 52 & 86.42 & 10.71 & 1.56 \\
\cline { 2 - 6 } & 11 to 30 & 54 & 83.91 & 12.57 & 1.53 \\
\cline { 2 - 6 } & $>30$ & & & & \\
\hline
\end{tabular}

How Familiar Would You Say You are with the ACRL Guidelines?

\begin{tabular}{|c|c|c|c|c|}
\hline Not Familiar & 7 & 82.86 & 17.50 & 6.61 \\
\hline Somewhat Familiar & 29 & 87.72 & 8.97 & 1.67 \\
\hline Neutral & 24 & 83.25 & 10.41 & 2.13 \\
\hline Very Familiar & 72 & 84.89 & 10.89 & 1.28 \\
\hline Extremely Familiar & 30 & 82.00 & 12.97 & 2.37 \\
\hline
\end{tabular}

\begin{tabular}{|l|c|c|c|c|c|}
\hline & $\mathrm{N}$ & Range & Minimum & Maximum & Mean \\
\hline Pedagogical & 162 & 54 & 59 & 113 & 85.16 \\
\hline Andragogical & 162 & 69 & 51 & 120 & 84.53 \\
\hline Total Raw Score & 162 & 75 & 134 & 209 & 169.69 \\
\hline Standardized Score & 162 & 2.893 & -2.963 & -0.069 & -1.586 \\
\hline
\end{tabular}


scores on Hadley's original Educational Orientation Study. ${ }^{26}$ This finding is triangulated with contemporary studies in other disciplines where mean scores on adult learning orientations tend to be higher than those of the librarians in this study ${ }^{27}$ Equally, librarians' mean scores on adult learning orientation for this study were lower than those librarians measured by Naito in the 1980s. That finding is somewhat disturbing, and, as a result of these overall standardized scores, standard deviation scores on adult learning orientation measurement tended to be higher than expected.

How did this paradox emerge within library instruction, since this was not an intended consequence of the ACRL Standards? The ACRL Standards themselves are very inclusive of adult learning theories, so we must wonder how outside factors are influencing the profession in regard to information literacy.

What types of further training and professional development are needed to help apply the ACRL Standards with their original intent? How can we as educators in our academic libraries help to develop curricula that are less pedacentric? What are the next steps for curriculum development in our LI programs?

Although I do not claim to hold the answers to these questions, I believe that, as an academic librarian who has been actively engaged in both teaching and research on library instruction throughout my career, it is time for us as a profession to address these difficult questions. I present the following propositions in an attempt to begin a much deeper conversation within the ACRL community, and I encourage other librarians to add to this list.

\section{Proposition 1: Define the role of academic librarian as adult educator}

There is an obvious philosophical struggle among academic librarians to distinguish between education/teaching and what we do in the library instruction classroom. This has been shown in different stud- ies, and most recently Walter's ${ }^{28}$ research has detailed our somewhat dichotomous beliefs in how we perceive our work. To say, "I am a librarian, not a teacher" is baffling at best and, at worst, reinforces to our faculty peers in other disciplines in the academy that our profession has not matured to a point where we can be recognized as being on equal footing in the teaching enterprise. Library instruction exemplifies the teaching and learning process if done effectively. If that is the case, then we are educators, and we must draw from educational theories to develop our library instruction curricula in both physical and virtual environments in the future, particularly since we appear to have no strong curriculum theories emerging from library science programs. This would involve a return to the original intent of the ACRL Standards: teaching students critical reflection skills in conducting research; teaching students how to be self-directed in their learning about library research; and teaching students how to be lifelong learners with library research. In essence, this is a focus on teaching students how to learn about library research rather than the pedagogically oriented focus toward discrete units of information. In effect, librarians should focus less on lecturing and more on facilitating in the classroom. Moreover, this same epistemology can be incorporated into emerging librarian teaching roles in media literacy and visual literacy.

At the opposite extreme is the instructional curriculum that emphasizes "here is where you click." If we do not focus our attention on teaching students how to learn-skills that can carry them well into the future-then we must address whether library instruction responsibilities should be consumed by the work of professional librarians, particularly in an era of economic uncertainty and staff shortages. If a particular institution has no formal library instruction curriculum and chooses to focus on "point and click" in the classroom, then I would argue that library might be 
better served having library graduate assistants perform the majority of the instructional loads.

\section{Proposition 2: Create a Library Instruction curriculum at the institutional level}

So, now that we have had the ACRL Standards in place for many years, how have we formally integrated them into the curriculum plan at our individual institutions? "Oh," you might be saying, "but we don't have a curriculum plan at our library." This is an understandable phenomenon, since teaching in the classroom - both physical and virtual-is a relatively recent experience for academic librarians when compared to peers in other disciplines. And I want to preface this proposition that curriculum plans should not be prescriptions for teaching and learning with no autonomy by the instructor to customize the curriculum to the environment! However, curriculum plans should provide a roadmap for the theory, content, timeframe, and instructional levels that can be used by all librarians at an institution teaching specific subjects. If your library has not done so already, begin work to formalize in writing what has been discussed in your library instruction teams or committees for many years. And while you are doing this, make sure to have a copy of the ACRL Standards in front of you to look for areas of synthesis, innovation, and convergence for your own curriculum plan. ${ }^{29}$

\section{Proposition 3: Focus ACRL professional development opportunities in instructional librarianship on how to be better educators.} This would involve a dedicated effort on the part of the Association, as well as us as academic librarians, to engage with scholars and practitioners in educational fields both at the national level and locally on our individual campuses. From instructional technologists to curriculum theorists, we have several opportunities to work directly with, learn from, and teach our colleagues in other fields. ${ }^{30}$ We are in an evolutionary period in higher education where we see evidence on almost a daily basis for the importance of interdisciplinarity and multidisciplinarity. Additionally, I would argue that we as a profession have historically been leaders on university campuses in developing partnerships with different disciplines. I advocate we take this one step further in encouraging professional development opportunities with our educational colleagues that will benefit our profession and lend to the improvement of quality outcomes for student learning on our campuses whether they be physical or virtual. Granted, we are not the only discipline in higher education that can benefit from these types of professional development. However, I would argue it is critical for our discipline to be proactive in leading engagement in these types of activities, as the profession continues to transition with corresponding changes in higher education.

\section{Proposition 4: Actively engage with graduate programs in Library Science and Education to promote the growing need for the study of educational and curriculum theories in our profession.}

This proposition challenges library science curricula to confront this disparity by engaging more heavily in the incorporation of teaching and learning theories into MLS programs. ${ }^{31}$ We have seen a great number of interdisciplinary approaches in library science programs, including curricula that include external coursework in disciplines such as business, law, history, sociology, and computer science. However, as stated previously, the research continues to show that teaching and learning has not been a focus of this interdisciplinary movement, while Naito's original study showed that librarians who had coursework in educational theory tended to be more adult learning oriented. ${ }^{32}$ Most recently, Shank and Dewald's study on instructional skill sets of recent MLS graduates showed that 94 percent of deans and directors either agreed (36\%) or strongly agreed $(58 \%)$ that the "ability to create a 
learner-centered teaching environment" is a "necessary or required" instructional skill set for today's academic librarians. ${ }^{33}$ Moreover, while much research among the American Society for Information Science \& Technology (ASIST) publications has focused on informatics or information-seeking behaviors as phenomena of scholarly communication, little research has been conducted to investigate the influence of teaching and learning theories on environmental changes to information-seeking behaviors and subsequent informatics. Equally, research on teaching and learning theories in relation to the preparation of instructional librarians is almost nonexistent in ASIST publications. I find this perplexing, since professional librarians are confronted with the growing - if not front-and-center-importance of educational responsibilities in the future. If MLS programs do not see value in this, then I propose we as a profession seek out educational opportunities among colleges of education at our own institutions to begin partnerships on the future of theory building in library instruction.

\section{Summary}

In summary, we have now matured as a profession to move from observation and reporting, to testing theories from other disciplines, to theory building in our own discipline on teaching and learning. This article provides an overview of research investigating the prediction power of librarians' familiarity with the ACRL standards on adult learning orientation scores. Although not significant as a predictor, there was a nonlinear correlation between librarians' familiarity with the ACRL Standards and their adult learning orientation scores $(p=.047, t<.05)$, and mean adult learning orientation scores were lowest among those participants who identified as being extremely familiar with the ACRL Standards. Additional variables are included to investigate other influences on adult learning orientation scores. Results of the study showed high significance for the following variables: 1) gender $(\beta=0.213, p=0.008)$; 2) currently teach library instruction $(\beta$ $=.199, p=.025)$; and 3) the number of library instruction classes taught during the current year $(\beta=.199, p=.041)$. Further descriptive analyses stratified by variable on mean adult orientation scores shows great potential for future research on the influence of: experience in the classroom, geographic location of MLS-granting program, size of the institution in which a librarian works, and the management of people as a job function. Propositions are additionally included to help guide future conversations on library instruction development among ACRL professionals.

\section{APPENDIX A. Demographics Questionnaire}

1. Gender

2. Age

3. Do you hold an MLS/MLIS?

4. If so, from what college or university did you receive your MLS?

5. Do you hold any additional graduate degrees? 
6. Please list any additional graduate degrees and the university or college from which you received the degree(s).

7. How many years have you worked as a professional librarian?

8. Current college or university?

9. Current job title?

10. Do you serve in a management position at your work?

11. How many people do you supervise?

12. Would you rate the size of your academic library as: small, medium, large research?

13. Do you currently teach library instruction/information literacy courses?

14. Is library instruction/information literacy one of your main job functions?

15. Do you currently provide reference services to students regardless of whether it is your main job function?

16. How familiar would you say you are with the Association of College \& Research Libraries Guidelines for Information Literacy?

- Not Familiar: I am unaware of these guidelines.

- Somewhat Familiar: I have heard of them but do not know much about them.

- Familiar: I have read the guidelines at some point and have a basic understanding of them.

- Very Familiar: I have utilized the guidelines on more than one occasion and have thought of ways to integrate them into my own work.

- Extremely Familiar: I use the guidelines frequently.

\footnotetext{
Notes

1. Scott Walter, "Librarians as Teachers: A Qualitative Inquiry into Professional Identity," College \& Research Libraries 69, no. 1 (2008): 51-71.

2. Association of College \& Research Libraries, Information Literacy Competency Standards for Higher Education (Chicago: Association of College \& Research Libraries, 2000), available online at www.ala.org/ala/mgrps/divs/acrl/standards/informationliteracycompetency.cfm [accessed 1 November 2010].

3. Donald L. Gilstrap and Jason Dupree, "Assessing Learning, Critical Reflection, and Quality Educational Outcomes: The Critical Incident Questionnaire," College \& Research Libraries 69, no. 5 (2008): 407-26; Donald L. Gilstrap and Jason Dupree, "A Regression Model of Predictor Variables on Critical Reflection in the Classroom: Integration of the Critical Incident Questionnaire and the Framework for Reflective Thinking," Journal of Academic Librarianship 34, no. 6 (2008): 469-81.

4. ACRL, Information Literacy Competency Standards.

5. Association of College \& Research Libraries, Research Agenda for Library Instruction and Information Literacy (Chicago: Association of College \& Research Libraries, 1980/2000), available online at www.ala.org/ala/mgrps/divs/acrl/about/sections/is/projpubs/researchagendalibrary.cfm [accessed 1 November 2010].

6. Joan Pitt, Research in Information Literacy and Library Instruction Survey, Association of College \& Research Libraries Research and Scholarship Committee (Oct. 2010).
} 
7. John Dewey, Experience and Education (Indianapolis, Ind.: Kappa Delta Pi, 1998/1938); Eduard C. Lindeman, The Meaning of Adult Education (Norman, Okla.: Oklahoma Research Center for Continuing Professional and Higher Education, 1961/1926); José Ortega y Gasset, The Mission of the University, trans. Howard Lee Nostrand (New Brunswick, N.J.: Transaction Publishers, 1992); Robert Kegan, The Evolving Self: Problem and Process in Human Development (Cambridge, Mass.: Harvard University Press, 1982); Carl Rogers, Freedom to Learn: A View of What Education Might Become, 1st ed. (Columbus, Ohio: Charles Merill, 1969); Malcolm Knowles, The Adult Learner: The Definitive Classic in Adult Education and Human Resource Development (Houston, Tex.: Gulf Publishing, 1998); Mary Field Belenky et al., Women's Ways of Knowing: The Development of Self, Voice, and Mind (New York: Basic Books, 1986).

8. Malcolm S. Knowles, The Modern Practice of Adult Education: Andragogy versus Pedagogy (New York: Association Press, 1970); Malcolm S. Knowles, The Adult Learner: A Neglected Species, 3rd ed. (Houston: Gulf Publishing, 1984); Malcolm S. Knowles, Andragogy in Action (San Francisco: Jossey-Bass, 1984); Brian L. Delahaye, David C. Limerick, and Greg Hearn, "The Relationship between Andragogical and Pedagogical Orientations and the Implications for Adult Learning," Adult Education Quarterly 44, no. 4 (1994): 187-200.

9. T. Neville Postlethwaite and Torsten Husen (eds.), "Andragogy." The International Encyclopedia of Education, 2nd ed. (Oxford, U.K.: Elsevier Science Ltd., 2011): 7-8.

10. Gerald O. Grow, "Teaching Learners to Be Self-Directed," Adult Education Quarterly 41, no. 3 (1991): 125-149; Delahaye, Limerick, and Greg, "The Relationship between Andragogical and Pedagogical Orientations," 1994; Paul Hersey and Kenneth H. Blanchard, Management of Organizational Behavior: Utilizing Human Resources, 5th ed. (Englewood Cliffs, N.J.: Simon \& Schuster, 1988).

11. Mark Tennant, Psychology and Adult Learning (New York: Routledge, 1997).

12. Gerald O. Grow, "In Defense of the Staged Self-directed Learning Model," Adult Education Quarterly 44, no. 2 (1994): 109-114.

13. V. DeCoux, J.R. Rachal, R. Leonard, and W.L. Pierce, A Quantitative Examination of Philosophical Predilections of Adult Education Graduate Students (East Lansing, Mich.: National Center for Research on Teacher Learning, 1992), ERIC Document Reproduction Service No. ED355433; A.C. Christian, A Comparative Study of the Andragogical-Pedagogical Orientation of Military and Civilian Personnel (doctoral dissertation, Oklahoma State University, 1983), Dissertation Abstracts International, 44, 0643a; Tanju Deveci, "Andragogical and Pedagogical Orientations of Adult Learners Learning English as a Foreign Language," New Horizons in Adult Learning 21, no. 3/4 (2007): 16-28; Delahaye, Limerick, and Greg, "The Relationship between Andragogical and Pedagogical Orientations," 1994; Curtis Trent and James F. Johnson, "The Influence of Students' Values and Educational Attitudes on Their Evaluation of Faculty," Research in Higher Education 7 (1977): 117-25; Keith A. Miller, Administrative Roles in Helping Faculty Adapt to Adult Learners, U.S. Department of Education, ERIC Document Reproduction Service No. ED290195.

14. Marilyn Naito, A Study of the Andragogical/Pedagogical Education Orientation of Academic Bibliographic Instruction Librarians (doctoral dissertation, Florida State University, 1996).

15. Theresa Westbrock and Sarah Fabian, "Proficiencies for Instruction Librarians: Is There Still a Disconnect between Professional Education and Professional Responsibilities?" College \& Research Libraries 71, no. 6 (2010): 569-90; Diana D. Shonrock and Craig Mulder, "Instruction Librarians: Acquiring the Proficiences Critical to Their Work," College \& Research Libraries 54, no. 2 (1993): 137-49; Lynn Westbrook, "Passing the Halfway Mark: LIS Curricula Incorporating User Education Courses," Journal of Education for Library and Information Science 40, no. 2 (1999): 92-98; Rebecca Albrecht and Sara Baron, "The Politics of Pedagogy: Expectations and Reality for Information Literacy in Librarianship," Journal of Library Administration 36, nos. 1-2 (2002): 71-96; Marsha Forys, "The University Library's Role in Developing Future Librarian Teachers: The University of Iowa Libraries' Experience," College \& Research Libraries News 65, no. 2 (Feb. 2004): 67-73.

16. Herschel N. Hadley, Development of an Instrument to Determine Adult Educators' Orientation: Andragogical or Pedagogical (doctoral dissertation, Boston University, 1975). Instrument can be found on 141-42.

17. William G. Cochran, Sampling Techniques, 3rd ed. (New York: John Wiley \& Sons, 1977); James E. Bartlett, II, Joe W. Kotrlik, and Chadwick C. Higgins, "Organizational Research: Determining Appropriate Sample Size in Survey Research," Information Technology, Learning, and Performance Journal 19, no. 1 (2001): 43-50.

18. Jacob Cohen and Patricia Cohen, Applied Multiple Regression/Correlation Analysis for the Behavioral Sciences, 2nd ed. (London: Lawrence Erlbaum Associates, 1983); Sam Kash Kachigan, Multivariate Statistical Analysis, 2nd ed. (New York: Radius Press, 1991); Jacob Cohen, Statistical Power Analysis for the Social Sciences, 2nd ed. (New York: Lawrence Erlbaum, 1988).

19. Naito, A Study of the Andragogical/Pedagogical Education Orientation of Academic Bibliographic 
Instruction Librarians, 95-97.

20. Gilstrap and Dupree, "A Regression Model of Predictor Variables on Critical Reflection in the Classroom," 2008.

21. Naito, A Study of the Andragogical/Pedagogical Education Orientation of Academic Bibliographic Instruction Librarians.

22. Agneta Lind, "Reflections on Mainstreaming Gender Equality in Adult Basic Education Programmes," International Journal of Educational Development 26, no. 2 (2006): 166-76; Aimee Callahan, Leann M.R. Kaiser, Elizabeth Erichsen, and Kelsee Miller, "Our Quest: How We Negotiate Our Multiple Selves on a Daily Basis," Journal of Adult Education 38, no. 2 (2009): 1-18; Mary Alice Wolf, "Older Adult Women Learners in Transition," New Directions for Adult and Continuing Education, no. 122 (2009): 53-62; Annemarie Vaccaro and Cheryl D. Lovell, "Inspiration from Home: Understanding Family as Key to Adult Women's Self-Investment," Adult Education Quarterly 60, no. 2 (2010): 161-76; Kimberly R. Burgess, "Social Networking Technologies as Vehicles of Support for Women in Learning Communities," New Directions for Adult and Continuing Education, no. 122 (2009): 63-71; Gaetane Payeur, "Woman as Adult Educators: Contributions to a New Leadership," Adult Learning 4, no. 5 (1993): 12-24; Michael W. Williamson and Claudia M. Greenwood, "The Nontraditional Student of the 1990s: Adults Re-entering College," Research E Teaching in Developmental Education 5, no. 2 (1989): 69-79; Lesley S.J. Farmer, Student Success and Library Media Programs: A Systems Approach to Research and Best Practice (Westport, Conn.: Libraries Unlimited, 2003).

23. Naito, A Study of the Andragogical/Pedagogical Education Orientation of Academic Bibliographic Instruction Librarians, 109, 168; Albrecht and Baron, "The Politics of Pedagogy," 89.

24. Naito, A Study of the Andragogical/Pedagogical Education Orientation of Academic Bibliographic Instruction Librarians, 160.

25. Carrie Donovan, quoted in Brenda L. Johnson, "Transforming Roles for Academic Librarians: Leading and Participating in New Partnerships," Research Library Issues, 14, available online at http://publications.arl.org/rli272/8 [accessed 20 November 20 2010].

26. Naito, A Study of the Andragogical/Pedagogical Education Orientation of Academic Bibliographic Instruction Librarians; Hadley, Development of an Instrument to Determine Adult Educators' Orientation; Keith Miller, "Administrative Roles in Helping Faculty Adapt to Adult Learners," paper presented at the American Educational Research Association Annual Meeting (Boston, Mass., Nov. 5-8, 1987).

27. DeCoux et al., A Quantitative Examination of Philosophical Predilections; Deveci, "Andragogical and Pedagogical Orientations of Adult Learners"; Miller, "Administrative Roles in Helping Faculty Adapt to Adult Learners."

28. Walter, "Librarians as Teachers."

29. Bern Mulligen et al., "Critical Research Practices at Binghamton University: A Case Study in Collaboration," College E Research Libraries News 69, no. 7 (July/Aug. 2008): 382-85; Gilstrap and Dupree, "Assessing Learning, Critical Reflection, and Quality Educational Outcomes."

30. Cara Bradley, "The Scholarship of Teaching and Learning: Opportunities for Librarians," College \& Research Libraries News 70, no. 5 (May 2009), pp. 276-78.

31. Marsha Forys, "The University Library's Role in Developing Future Librarian Teachers: The University of Iowa Libraries' Experience," College $\mathcal{E}$ Research Libraries News 65, no. 2 (Feb. 2004): 67-73.

32. Naito, A Study of the Andragogical/Pedagogical Education Orientation of Academic Bibliographic Instruction Librarians, 136-44.

33. John D. Shank and Nancy H. Dewald, "Academic Library Administrators' Perceptions of Four Instructional Skills," College E Research Libraries 73, no. 1 (Jan. 2012): 84-85. 